Portland State University

PDXScholar

1976

\title{
Economic Coping Patterns of Chinese Foreign Students in Portland State University
}

\author{
Kim Bik Au \\ Portland State University
}

Follow this and additional works at: https://pdxscholar.library.pdx.edu/open_access_etds

Part of the Social Work Commons

Let us know how access to this document benefits you.

\section{Recommended Citation}

Au, Kim Bik, "Economic Coping Patterns of Chinese Foreign Students in Portland State University" (1976). Dissertations and Theses. Paper 1810.

https://doi.org/10.15760/etd.1809

This Thesis is brought to you for free and open access. It has been accepted for inclusion in Dissertations and Theses by an authorized administrator of PDXScholar. Please contact us if we can make this document more accessible: pdxscholar@pdx.edu. 
LD 349
$A 84$
1976
. A49
PS. Libury

ECONOMIC COPING PATTERNS OF

CHINESE FOREIGN STUDENTS IN

PORTLAND STATE UNIVERSITY

by

KIM BIK AU

A report submitted in partial fulfillment of the requirements for the degree of

MASTER OF

SOCIAL WORK

Fortland State University

1976 
TABLE OF CONTENTS

PAGE

LIST OF TABLES . . . . . . . . . . . . . . .

CHAPTER

I. INTRODUCTION ................ . . . 1

Purpose of This Study . . . . . . . . . 3

Definition ............... 3

II. METHODOLOGY . . . . . . . . . . . 5

Population and Sample . . . . . . . . . 5

Collecting and Organization of Data . . . . . б

Schedules . . . . . . . . . . . . 7

Pretest ................ . . 7

Statistical Design . . . . . . . . . 7

III. DATA ANALYSIS AND INTERPRETATION OF FINDING • . 8

General Characteristics of Respondents . . . . 8

Source of Income . . . . . . . . . . . 13

Coping Patterns . . . . . . . . . . . 20

Financial Situation . . . . . . . . . 23

IV. CONCLUSION . . . . . . . . . . . . 28

Implication of Social Work . . . . . . . 30

Discussion . . . . . . . . . . . . 33

BIBLIOGRAPHY . . . . . . . . . . . . . . . 35

APPENDIX . . . . . . . . . . . . . . . . . . 37 
LIST OF TABLES

TABLE

PAGE

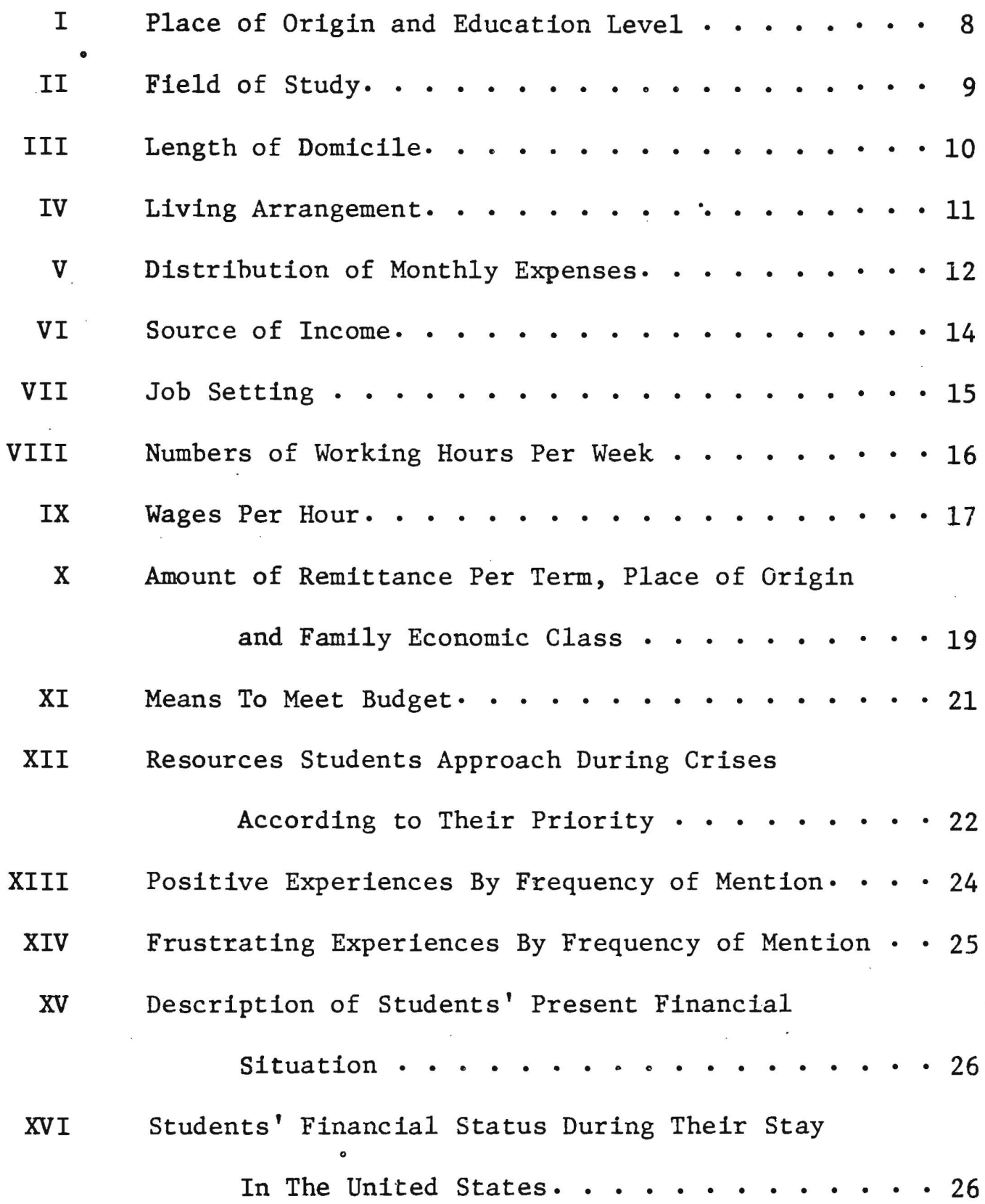




\title{
CHAPTER I
}

\section{INTRODUCTION}

\begin{abstract}
Foreign students coming from other countries to an unfamiliar place will encounter many intensified adjustment problems in terms of emotion, finance, language, living arrangement, personal relations and others. Among all the problems, financial adjustment is the most important one. In general there are a number of sources by which the foreign students support their education in the United States. Support ranges from complete self-support to complete reliance on others.
\end{abstract}

\section{Complete Self-support}

Students support themselves either by savings or work in order to maintain themselves without outside help.

\section{$\underline{\text { Partial Self-support }}$}

Students partially depend on sources such as parents, relatives, friends, government funds or loans, agencies and institutions for financial aid, at the same time supplementing these sources by working or savings.

\section{Complete Outside Help}

Students are fully supported by other financial resources. These may include money, services and meeting of needs in kind, from government, family, friends, agencies and institutions.

In spite of the precautions they had taken before coming to the 
United States students often face financial embarrassment. Many factors may affect the financial status of a foreign student as stated in "Counselling Foreign Student":

Among the causes of financial embarrassment ... are (1) the dollar shortage and the consequent limitation by foreign governments of dollar purchases by students or their representatives; (2) incomplete and misleading budget information in college and university catalogues and bulletins; (3) national emergencies and catastrophes; (5) inflation of the dollar; (6) family emergercies affecting the source of the student's funds and (7) personal emergencies such as 111 ness, unexpected travel needs and delay in authorization of foreign exchange. 1

Unexpectedly higher costs of living, as for rent, food or tuition often upset the financial plan of foreign students. A report from Education and World Affairs in 1964 illustrated that the difficulty of foreign students was recognized:

On the financial side, many foreign students come to the United States with insufficient funds to enable them to reach their immediate educational objectives. Since they must maintain status as full-time students during the regular academic year or forfeit renewal of their student visas, frequent financial crises arise with which the host institution must dea 1.2

However, financial assistance available for foreign students from the host country is limited. Usually the form of assistance will be either waiver or reduction of tuition fee. This is not available to every applicant who is in need. On the other hand, foreign students are prohibited from working off campus without a work permit in accordance with federal regulations. The situation becomes more difficult as "the trend in the United States to withdraw or withhold financial

1 Theodore C. Blegen, Counselling Foreign Students (Washington: American Council on Education, 1950), P. 19.

2 The Foreign Student: Whom Sha11 We Welcome (Education and World Affairs, New York, 1964), P. 4 . 
support has increased markedly in the past few years." 1 This can be illustrated by the rigidity in applying a work permit. Viewing all the pressure and restrictions which are impinging upon foreign students, their potential of adjustment in connection with the financial situation is worth exploring.

PURPOSE OF THIS STUDY

The nature of this study is exploratory. It afms to explore the financial situation and the resources which students can use to cope with their problems. The primary purpose is to obtain a clearer picture of the situations of certain Chinese foreign students, to help those who intend tc study abroad with their budgeting and planning. A secondary aim is to draw the attention of authorities concerned to improve or expand services to foreign students who already have overwhelming adjustment problems and who still have to carry the additional burden of pressure from restrictive regulations.

\section{DEFINITIONS}

\section{Foreign Student}

The definition of foreign student as given by UNESCO is: "...a foreign student is a person enrolled at an institution of higher education in a country of which he is not a permanent resident."2

They are holding a student visa and therefore, are restricted by

1 Helen I. Clark \& Martha Ozawa, The Foreign Student in The United States, (The University of Wisconsin 1970), P. 12.

2 United Nations Educationa, Scientific and Cultural OrganizationDocument (Paris, UNESCO, 1972), P. 3. 
certain regulations of the immigration office; for example, employment restriction.

\section{Coping Patterns}

According to David Mechanic ${ }^{1}$, in dealing with crisis situations people will use coping and defense mechanisms. Coping mechanisms deal with the actual situation while defense mechanisms deal with the emotional level which derives from the situation. Economic coping patterns in this study refer to those practical ways which students use to deal with their financial situation both in general and during crisis.

1 David Mechanic, Students Under Stress, (New York: The Crowe11Cullier, 1962), P. 85 . 


\section{CHAPTER II}

\section{METHODOLOGY}

\section{Population and Sample}

The population of this study is comprised of Chinese foreign students of Portland State University from Taiwan and Hong Kong. Since a complete name-1ist of Chinese students was not available, I could not use the method of random sampling or any other systematic method. The name-1ist obtained from the Chinese Student Association of Portland State University included the names of Chinese students from Taiwan but only a few of those who came from Hong Kong. After consultation with the president of the Chinese Student Association of Portland State University I interviewed those students who are within the criteria of my study and whose names were on the 1ist. Since many names of students coming from Hong Kong were not included on the list, I tried to locate each of them from every possible resource, including information from my friends and requests for information from each interviewee and those I met on the campus. At the end of this survey I managed to fill in some of the names and adaresses of students coming from Hong Kong for the name-list of the Chinese Student Association.

I collected data on thirty-one students coming from Taiwan or Hong Kong. They were very cooperative in answering my questions except for one who refused to answer any questions, thus reducing the total number of the sample to thirty. The representativeness of thirty students is doubtful since the percentage of this sample in the whole 
population of Chinese foreign students in Portland State University is unknown. (From informal sources the number of Chinese foreign students at Portland State University appeared to be about thirty-five during the year 1975-76. However there is no official confirmation obtainable.) I will not generalize from these thirty. However, the analysis may illustrate some of the general phenomena.

\section{Collecting and Organization of Data}

For collecting data I conducted a structured interview in which a schedule was used. (see Appendix I) By using the schedule, uniform and standardized answers which were kept in a frame of reference could be assessed and analyzed. I administered the schedule myself so that I could interpret in our own dialect, to avoid misunderstanding and norresponse. Financial situation is a sensitive subject, especially in Chinese culture which is more conservative. Chinese people are reluctant to expose their private life to outsiders, particularly in connection with financial issues. Besides, the pressure of regulations and restrictions which they are under intimidate their will to reveal their situation openly and completely. Verbal assurances of confidentiality about information proved to be helpful during the interviewing process when personal information was explored. The other method I used was casual conversation. In casual conversation without the questionaire students were more relaxed in discussing their problems. I worked along this line with several individuals and could understand their situation more in depth and at the same time was able to appraise the reliability of the information given in the schedule. I could not countercheck all persons in the sample by means of this method because I did not have the 
opportunity to meet all of them again on a casual basis.

Schedules were printed in English but questions were asked in

elther Cantonese or Mandarin, whichever was applicable.

The data were coded, tallied and classified by IBM card sort.

Schedules

There were twenty-three questions, not all applicable to each student's situations. (see Appendix I) If a respondent was not sure of a meaning or interpretation, explanation was given in Mandarin or Cantonese. Little explanation was called for, however, a considerable amount of reassurance had to be given when asking about the working situation. Regarding other questions, students seemed to feel comfortable in responding.

\section{Pretest}

Before the schedule was printed the questions were asked among my friends, ten of whom were included in my sample, for the purpose of pretesting. Then, the questions were revised and rephrased several times so that the meaning became clear and misleading answers could be avoided.

\section{Statistical Design}

Simple depictive statistics were judged appropriate. Tables with percentage distributions were used to help to analyze the data. 
CHAPTER III

\section{DATA ANALYSIS AND INTERPRETATIONS OF FINDINGS}

\section{General Characteristics of Respondents}

\section{Educational Leve1 and Place of Origin}

Out of the thirty persons interviewed, fourteen were male and sixteen were female. All the Taiwan students were in graduate programs except one, as seen in the following table.

TABLE I

PLACE OF ORIGIN AND EDUCATION LEVEL

$\begin{array}{lcc}\text { Origin } & \text { Undergraduate } & \text { Graduate } \\ \text { Hong Kong } & 13 & 7 \\ \text { Taiwan } & 1 & 9 \\ \text { Total } & 14 & 16\end{array}$

The policy of the Taiwan government narrowly restricts students for undergraduate study abroad. In the sample as a whole, fourteen were in the undergraduate program and sixteen were graduate students. Twenty came from, Hong Kong and ten from Taiwan. All of them whether from Hong Kong or Taiwan, shared the same Chinese culture in terms of traditional background and philosophical perspectives. All of them also used the same written language. Even though there is geographical distance between these two places, no significant difference was observed as far as economic coping patterns are concerned. This will be illustrated 
later in the study.

Field of Study

Table II shows the field in which the students were studying.

Half of the sample was in the area of business.

TABLE II

FIELD OF STUDY

Major

Hong Kong

- Taiwan

Business

10

5

Science

5

3

Social Science

1

Humanities

0

1

Total

There is no significant difference in field of study in terms of place of origin as shown in Table II.

\section{Length of Domicile}

Thirteen out of thirty have been here for approximately two years. Having accommodated to an unfamiliar environment for two years they are more comfortable in dealing with their daily lives. The most important point is that they can be more familiar with the new environment and are more capable of reaching out for possible resources such as friends, financial agencies or jobs if in financial stress. Table III shows the distribution of the sample in terms of approximate length of domicile up to 1976 . 
TABLE III

LENGTH OF DOMICILE

Frequency

One year

Two oyears

Three years

Four years

Five years

Six years

Total

\section{7}

13

3

2

4

1

30
Percent

23

43

10

7

13

3

100

\section{Living Arrangemients}

The students from abroad were in every case bewildered in locating acceptable housing. Some universities provide housing bureaus which make it easier for students to get through this process. In some instances the university has the facilities of dormitories and prearrival arrangements can be made; otherwise, housing arrangements have to be made upon arrival. There are many problems associated with housing

for foreign students. Clark pointed out seven general problems:

First, contracts are generally required... Students do not always understand the implications of such contracts and leases nor the liabilities attached to violations of provisions. Second, rental prices...often startle foreign students and upset budgetary planning. Third, some foreign students complain of discrimination. Fourth, foreign students complain of inadequate facilities especially in the lower cost facilities. Fifth, negative reaction is expressed to American food and its prepar-

- ation. Sixth, there are inadequate housing resources for undergraduate or graduate students. Seventh, problems of transportation are linked with those of housing. Students without cars, prohibition of cars on campus, infrequency and inadequacy of bus 
service are conditions which aggravate the difficulty of finding satisfactory housing. 1

Table VI shows the living arrangements of the students.

TABLE VI

LIVING ARRANGEMENT

Category

With Friends

Alone

With Relatives

With Spouse Only

With Spouse and

Children

Other

Total
Apartment

7

0

3

1

0

1

14

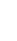

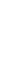

1

0

1

\section{Student}

Housing

1

9
House

2

1

1

0

0

1

1

3

As shown in Table VI most students live with friends in apartments. The reason is that sharing accommodations can reduce the high cost of housing. Some share their meals, but some do not. Either way, sharing accommodations reduces costs. It would be economical to live in student housing if there were some resources to get needed furniture. One respondent revealed that she picked up almost all of her furniture on the street and that she and her husband renewed it. All in the sample expressed that it was not feasible to purchase new furniture because of the expense and also because it was inconvenient to move. The mobility rate is high among foreign students and they have to leave this county

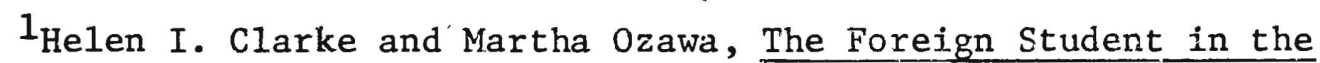
United States, (The University of Wisconsin, 1970), P. 60 . 
eventually. In the sample, a large number of students lived in apartments because of the limitation of other facilities. A preferred place is often not available for students in need of a place to stay almost immediately. Besides, the furnishing of a house is also a problem to some of the students. That is why students have to rent a furnished apartment instead. In any case, sharing with friends is a customary and practical way to solve the housing problem.

The major expenses for students are for housing and food. Table V shows the monthly distribution of expenses. Each category of expenditure is independent.

\begin{tabular}{cccccc} 
& \multicolumn{5}{c}{ TABLE V } \\
$\%$ & DISTRIBUTION OF MONTHLY EXPENSES & Thing \\
$0-10$ & 2 & Food & Clothing & $\begin{array}{c}\text { Transpor } \\
\text { tation }\end{array}$ & Other \\
$11-20$ & 1 & 3 & 30 & 24 & 10 \\
$21-30$ & 9 & 13 & 0 & 5 & 9 \\
$31-40$ & 7 & 8 & 0 & 0 & 7 \\
$41-50$ & 9 & 3 & 0 & 0 & 1 \\
$51-60$ & 2 & 1 & 0 & 1 & 1
\end{tabular}

On the average, monthly expenses were distributed as follows, in percentages:

$\begin{array}{lr}\text { Housing } & 33.67 \% \\ \text { Food } & 28.80 \% \\ \text { Clothing } & 5.00 \% \\ \text { Transportation } & 8.00 \% \\ \text { Miscellaneous } & 18.33 \%\end{array}$


The two respondents who used the least for food and housing were living with relatives and supported by them. Students who paid less for rent tend to spend more on food. It is not surprising to find that only a minimal amount was spent on clothing because it is common for Chinese foreign students to bring their clothes directly from their home country. The main reason is to avoid expenditures in dollars, which would add to the financial burden. Most of the time clothes were much cheaper when purchased in Taiwan or Hong Kong. Students responded that they might have only to buy one heavy coat for the Winter. However, the weather in Portland is not drastically different from either Taiwan or Hong Kong and students found that the clothing they brought was sufficient for the weather here.

As for transportation, expenses were small due to the fact that most of the students lived near or on campus and only a few living in town beyond walking distance had to catch a bus or have a car.

The other major category besides food and housing was "miscellaneous". Among these the major expenses were for entertainment, books and telephone. About $30 \%$ of the sample indicated that they used $15 \%$ of their expenses on entertainment, including movies, traveling and social gatherIngs with friends. They said that entertainment in whatever style could help them relax and they found it beneficial for recovering from frustrations.

Source of Income

The majority of the sample (57\%) had more than one source of income and $17 \%$ had more than two sources of income. Due to inflation during recent years, students felt that it was difficult to suppcrt themselves 
by means of one source. Besides, they felt more secure in having alternatives if one of the sources failed unpredictably to give sufficient support. Table VI shows the sources of income of the sample up to the time this survey was conducted, December 1975. It should be noted that the tally has been made on the basis of frequency of mention, the same individual may have been tallied more than once if he mentioned more than one source of income. Consequently, the total sources of income listed in the table would be more than thirty.

TABLE VI

$$
\text { SOURCE OF INCOME }
$$

$\begin{array}{lcc}\text { Category } & \text { Frequency } & \text { Percent } \\ \text { Employment } & 19 & 33 \\ \text { Financial Aid } & 13 & 22 \\ \text { Family } & 13 & 22 \\ \text { Savings } & 9 & 16 \\ \text { Loans } & 0 & 0 \\ \text { Total } & 58 & 100\end{array}$

Employment. More and more foreign students in the United States find it necessary to seek employment for economic reasons and the drive for independence especially when the student's family is making great sacrifices to send dollars. Even though they are limited by visa terms on the amount and place they can earn and work, foreign students can still be employed with or without the work permit. On the other hand, they did not experience difficulty finding jobs.

Fourty-four percent of those who worked got their first job in less than two weeks and thirty-four percent in less than two months of 
seeking. Students are mostly accepted for on-campus jobs. Fifty-three percent of the working sample were working as librarian assistants or working in the food service of Portland State University. Though wages for on-campus jobs were less than for outside jobs, students did not have to work under the pressure of being "illegally working" and shadowed by possible consequences which might result, such as deportation. However, students, thirty-three percent of the working sample, had to look for outside jobs despite the risk they were taking because on-campus jobs were not always available or because they needed to earn more money for subsistence.

None in the sample got his/her job through any employment guidance program, if it existed, in the university. Students were also too timid to ask for advice about taking an outside job. They were afraid of the implications which might be involved. About thirty-seven percent of the working sample worked both during school terms and in Summer, while another thirty-seven percent worked all year around, i.e. school terms, Summer and quarter breaks. They might work in different jobs at different times. Table VII shows the period of time and type of job during the period from September 1974 to september 1975 of all those employed.

TABLE VII

JOB SETTING

$\begin{array}{lccc}\text { Periods } & \text { Restaurant/Hotel } & \text { Office } & \text { Factory } \\ \text { School Terms } & 7 & 11 & 0 \\ \begin{array}{l}\text { Summer } \\ \text { Quarter Breaks }\end{array} & 10 & 6 & 1 \\ \text { Total } & 19 & 6 & 0 \\ & & 23 & 1\end{array}$


The majority of students were working in office positions such as the library, academic departments and student publications. Only two of the respondents were working in outside firms.

Students worked more hours in Summer and during quarter breaks. Table VIII indicates the number of working hours per week during different periods of time.

TABLE VIII

NUMBERS OF WORKING HOURS PER WEEK

$\begin{array}{lccc}\text { Hours } & \text { School Terms } & \text { Summer } & \text { Quarter Breaks } \\ \text { Less than } 10 \text { hours } & 1 & 2 & 0 \\ 11-15 \text { hours } & 8 & 2 & 2 \\ 16-20 \text { hours } & 6 & 2 & 1 \\ 21-30 \text { hours } & 2 & 4 & 2 \\ 31-40 \text { hours } & 1 & 5 & 3\end{array}$

The average number of working hours per week were:

School Terms 17 hours/week

Summers 26 hours/week

Quarter Breaks 26 hours/week

Students worked more hours in Summer and during quarter breaks. They were very cautious about the number of working hours and would not overload themselves by work during school terms when more time had to be used on their study.

Their wages are shown in Table IX. 
TABLE IX

WAGES PER HOUR

$\$$

Less than 2.00

$\$ 2.10-2.50$

$\$ 2.60-3.50$

$\$ 3.60-5.00$

$\$ 5.10-6.00$
School Terms

0

3

7

3

5
Sumner

0

7

4

3

3
Quarter Breaks

0

3

3

1

1

There is no obvious difference in wages during different periods of time. During school terms seven out of eighteen students were paid within the range of $\$ 2.60-3.50$ per hour. In Summer, seven students were paid $\$ 2.10-2.50$ per hour. During vacations such as summer and quarter breaks more students were looking for jobs. When work is labor Intensive, wages do not have to be raised to recruit employees. According to the immigration regulations students had to have a work permit at any time to work off campus. About sixty-eight percent of the working sample acknowledged that a work permit is required while working in off-campus jobs. Some fifty-two percent had tried to apply for a work permit but only thirty-seven percent of them had obtained a work permit. Ninety-five percent who were working did not have a work permit. Among them forty-seven percent took jobs off campus. Students who did not have a work permit and had never tried to apply at any time revealed that they were discouraged by regulations of the immigration office, especially during recent years. They were afraid to expose themselves to the authority concerned in case their applications were not accepted. The reason is that it would be easier for the immigration 
office to trace or inspect them if they had a record there. Even though they knew very well about the risk that they were undergoing by working without a permit, they saw no alternatives available for them to solve their financial problem.

Financial Aid. The types of financial aid at Portland State University available to foreign students are Foreign Student Scholarship, deferred tuition and short-term loans. The Foreign Student Scholarship is the only scholarship available for foreign students from various countries. The criteria for receiving the scholarship are assessed by financial need, country represented and priority of renewal students. Assistance given to students in 1975 on this program amounted to partial tuition. Among 130 foreign students who were receiving this scholarship for 1975-76 fifteen were Chinese foreign students. At this time this program provided no emergency funds for foreign students. 1

Among the eighteen students receiving aid from the university, fifteen were in the Foreign Student Scholarship Program as arranged by the Financial Aid Department of Portland State University. The other three were in the scholarship program offered by their own faculty - one was on a teaching assistantship and the other two were receiving a research assistantship. The amount of assistance from the Foreign Student Scholarship was according to the amount of tuition students had to pay. The average amount of assistance for undergraduate students was $\$ 500.00$ per quarter, and $\$ 200.00$ for graduate students. About forty-one percent of the sample receiving financial aid had applied for this scholarship before they came while thirty-five percent applied after they

1 Information given by Bessie M. Fields, Director, Foreign Student Program, Portland State University, by correspondence dated 12/11/75. 
came. Fifty-three percent received the grant in less than three months after they had submitted their application. Twenty-four percent had to wait for about six months and twenty-three percent were approved within six months to one year. Since the assistance is mainly for partial tuition about fifty-three percent of the sample indicated that the amount covered only one-fourth of their total expenses, which included tuition, housing, food, clothing, transportation and miscellaneous.

Family. Among the thirteen students whose source of income was from family or at least partially from family, ten were supported by parents, two by siblings and one by other relatives. Table $\mathrm{X}$ illustrates the amount of remittance sent ty family per quarter and also its relation to place of origin and family economic class.

TABLE X

AMOUNT OF REMITTANCE PER TERM, PLACE OF ORIGIN AND FAMILY ECONOMIC CLASS

$\begin{array}{lcccc}\text { Amount } & \text { Taiwan } & \text { Hong Kong } & \text { Middle } & \text { Upper-middle } \\ 100.00 & 0 & 1 & 1 & 0 \\ 101.00-300.00 & 0 & 1 & 0 & 1 \\ 301.00-500.00 & 0 & 1 & 1 & 0 \\ 501.00-800.00 & 0 & 1 & 0 & 1 \\ 801.00-1200.00 & 3 & 5 & 3 & 5 \\ 1201.00-1500.00 & 0 & 1 & 0 & 1 \\ \text { More than } 1500.00 & 0 & 0 & 0 & 0\end{array}$

Table $\mathrm{X}$ shows that students who came from Hong Kong relied more on family support than students from Taiwan. Three of the students from Taiwan described their families' economic status as "upper-middle" class. 
However, all of them were partially dependent on family remittance and supplemented their expenses by work. Considering the foreign exchange of currency between the United States and either Taiwan or Hong Kong (U.S.A. $\$ 1.00=$ H.K. $\$ 5.00$, U.S.A. $\$ 1.00=$ T.W. $\$ 38.05)$ it is a very heavy burden for a family to support students. Only the upper-middle class in Taiwan could afford to remit money to support the students due to the different currency exchange rate between Hong Kong and Taiwan. That is another reason why students seidom depended on family as the sole income, the three who came from Hong Kong and from the upper-middle class.

Savings. In the sample, nine included savings as a source of support. However, they did not intend to exhaust the amount without trying other alternatives, such as employment or applying for financial aid. It seemed more secure for them to have some money as savings for emergency use.

All felt that they could accurately estimate expenses before they came and the amount of money had lasted as they expected.

Loans. No student in the sample had received a loan.

\section{Coping Patterns}

It was unanticipated to find that in the sample as many as sixty percent of the students indicated that they had "almost never" been without sufficient money to meet expenses since coming to the United States. Twenty-three percent answered "sometimes" and seventeen percent replied "seldom". None of them revealed that they had experienced money crises since they had been here. Sometimes they would have a small deficit with their budget but usually they could resolve it without too much difficulty. 
Table XI illustrates the means which they had employed or would have probably used for meeting a deficient budget.

TABLE XI

MEANS TO MEET BUDGET

$\begin{array}{lcc}\text { Adjustments } & \text { Frequency } & \text { Percent } \\ \text { Find Employment } & 22 & 54 \\ \text { Cut Down Food Supply } & 4 & 12 \\ \text { Live in Place With Cheaper Rent } & 4 & 12 \\ \text { Change Employment For Higher Pay } & 4 & 12\end{array}$

Most students indicated that they already lived in a reasonably cheap place. Besides, alternative cheaper accommodations near the campus was very limited and they were not willing to live further away by reason of transportation complication. Changing to cheaper accommodation was always difficult to work out. They also felt that they were keeping their food expenses at a minimum. Therefore, finding employment was practically the only way to solve the problem. Some indicated that both housing (1iving in a reasonably comfortable place) and food (to keep one's health) were most important and they would not consider whatsoever cutting the expenses for these two. Three replied that they would try more than one alternative; namely, cut down food supply, move to cheaper places and at the same time look for employment.

To explore students' resources to meet financial crises such as 1llness or accidents which affected their financial situation, they were asked which resource in Table. XII they would approach for assistance and they were asked to indicate according to their priority. The results are shown in Table XII. 
TABLE XII

RESOURCES STUDENTS APPROACH DURING CRISES ACCORDING TO THEIR PRIORITY

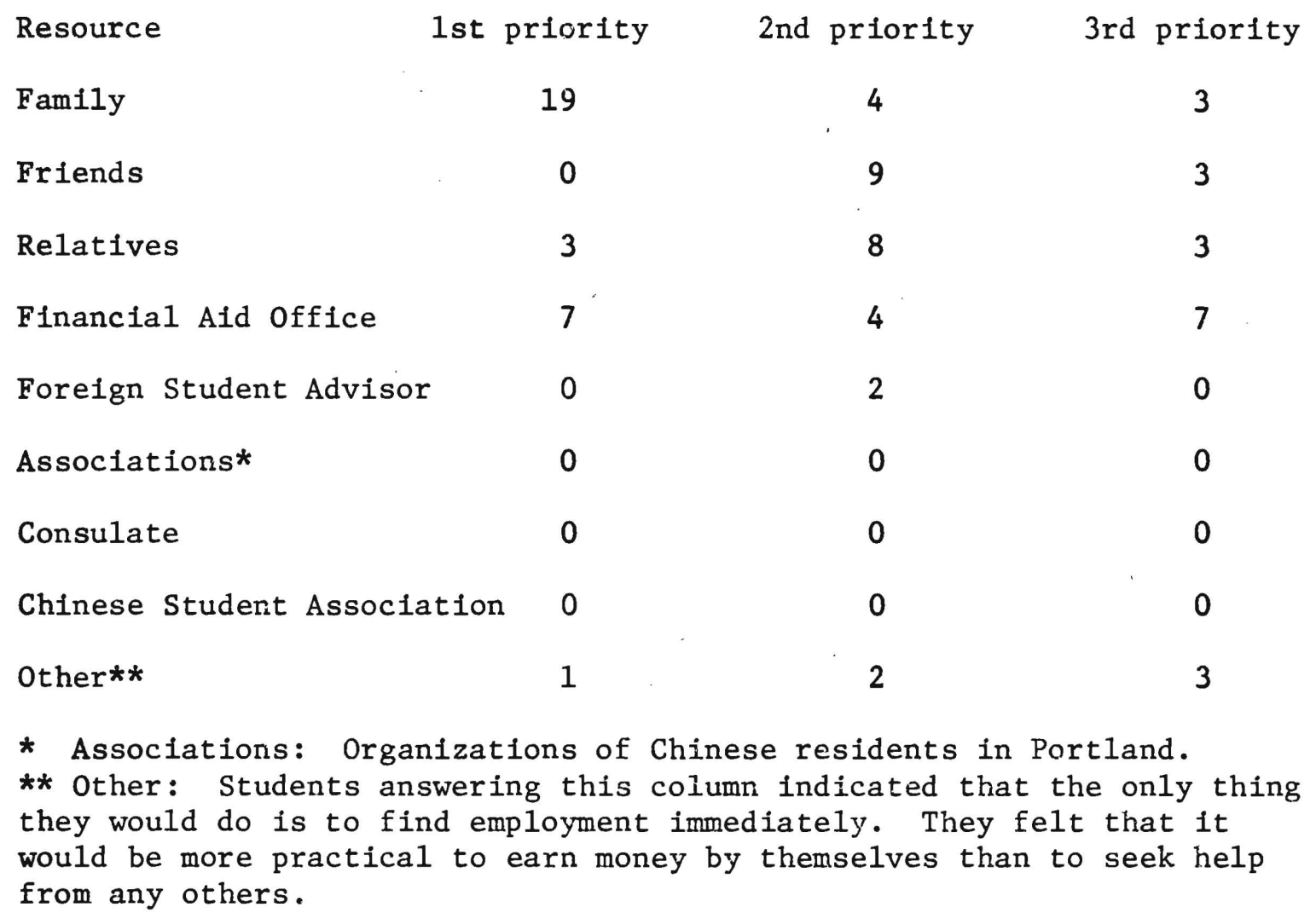

According to Table XII family is still the first priority in asking for financial assistance when facing crisis, regardless of the fact that immediate help could not be obtained due to the geographical distance. It could illustrate that students had only scarce resources which they could approach for assistance and not too many alternatives were offered: Students had rarely approached the Foreign Student Advisor for assistance. As also the research done by Terry Hu in 1974 indicated, "At Portland. State University no one even went to a foreign student advisor for help."1 Her research also indicated that:

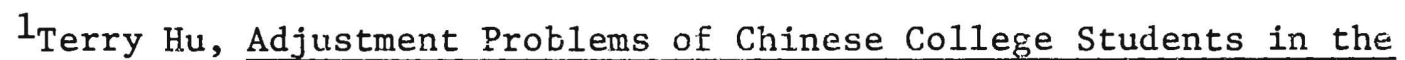
United States, (Oregon: Portland State University, 1974), P. 25. 
Foreign student services were mostly recognized by Chinese students in the sense that they were functions of an administrative office where students had to go in order to stay and work in this country as a foreign student. 1

Students thought that financial assistance would neither be available from Association or Chinese Student Association of Portland State University or the Consulate from the home country. Since they did not have any contact with the Chinese associations in Portland they would not approach them for assistance. Informal talk with one of the committee members at the Chinese Benevolent Association of Portland revealed that the Welfare Committee of the assocation only offered assistance to residents with technical problems in terms of visa or immigration regulations. Financial assistance was not available. There was also no financial aid whatsoever for Chinese students from the Chinese Students Association, as confirmed by the President of the Association. However, they would try their best to give advice on possible resources such as the Financial Aid Office for those asking for help. Most important, they would help to provide information on job hunting.

\section{Financial Situation}

To ascertain how important students consider their financial problems they were asked to 1ist three positive and three frustrating experiences that they might not have in their home country. The results are shown in Table XIII and Table XIV, indicating that some students consider coping with financial problems as a positive experience but some regarded this as a frustrating experience.

1op. cit., P. 25 . 
TABLE XIII

POSITIVE EXPERIENCES BY FREQUENCY OF MENTION

Category

Frequency

Freedom, independence 25

Athletic Activities such as skiing, hunting, driving, etc. 5 Traveling Wider Educational Scope

Get away from nosy relatives

Self privacy

Have the experience of budgeting

Learn more new ideas and concepts

Work while studying

Improve language ability

Self support

Know how to deal with "foreigners"

Opportunities to get to know host country better Cultural exchange

Proper training in the field of study

Can be admitted to university

Use of scientific method

Change of study attitude

Better study environment

Working as a janitor

Find a good boy friend

Hard working ethics

Better living condition

Enrich life experience

None 
TABLE XIV

FRUSTRATING EXPERIENCES BY FREQUENCY OF MENTION

$\begin{array}{lr}\text { Category } & \text { Frequency } \\ \text { Language difficult } & 12 \\ \text { Racial and social discrimination } & 10 \\ \text { Lack of social life } & 7 \\ \text { Financial problem } & 4 \\ \text { Cannot work } & 4 \\ \text { Cultural gap } & 3 \\ \text { Heavy study load } & 3 \\ \text { Home sickness } & 3 \\ \text { Poor food } & 3 \\ \text { Cost of transportation } & 2 \\ \text { Ignorance of people in the host country about home country } & 2 \\ \text { Low grade point } & 2 \\ \text { Limited job market } & 1 \\ \text { Scholarship cannot even cover the expenses of tuition } & 1 \\ \text { Failure to get scholarship } & 1 \\ \text { Rise in expenses } & 1 \\ \text { Cannot get work related with his own field } & \\ \quad \text { due to alien status } & 1 \\ \text { Lower working status } & 1 \\ \text { Poor living condition } & 1 \\ \text { Different thoughts and customs } & 1 \\ \text { Feel aliented because of different ethnic origin } & 1 \\ \text { Falled license test } & 1 \\ \text { Tougher in everyway } & 1 \\ \text { Noor attitude of immigration officers } & 1 \\ \text { Marriage } & 1 \\ \text { No frustrations } & 1 \\ \end{array}$

According to Table XIV students considered financial problems as a prime source of frustrating experience. This was mentioned seventeen times in different categories which had connection with the financial issue.

- Students were then asked to describe their present financial situation, as shown at Table XV. 
TABLE XV

Category

Financially stable

If emergency happened would be in crisis
Frequency

22

8

The majority of students described that their financial situation was very stable. Students who were worrying about their economic situation indicated they would not have extra money to cover expenses if an emergency arose such as illness or accident. However, students' financial status during their stay in this country did not show that many had any drastic change, as shown in Table XVI.

TABLE XVI

\begin{tabular}{|c|c|c|c|c|}
\hline STUDENTS ' & $\begin{array}{l}\text { FINANCIAL STATUS } \\
\text { IN THE UNITED }\end{array}$ & $\begin{array}{l}\text { DURING THEIR } \\
\text { STATES }\end{array}$ & STAY & \\
\hline Category & 3 First & 3 Months & Recent & Future \\
\hline Very Adequate & 8 & 1 & 2 & 2 \\
\hline Adequate & 15 & 23 & 22 & 22 \\
\hline Inadequate & 1 & 4 & 4 & 1 \\
\hline Precarious & 1 & 0 & 0 & 3 \\
\hline No Response & 2 & 2 & 2 & 2 \\
\hline
\end{tabular}

Students who were in a precarious or inadequate situation either had not found a job or had not yet recelved financial aid. After three months, more students had established their financial situation and no student was in precarious situation. However, seven students changed from a very adequate situation to adequate. They revealed that the money they had brought with them was used faster than they expected because 
most of them did not know how to keep their budget. Students in an inadequate situation indicated that they felt inadequate because sometimes they failed to keep a balanced budget and they had to be cautious about their expenditures almost anytime.

Recently, the situation remained more or less the same except that one student had found a job on the campus and changed her situation from adequate to very adequate.

For the future students responded that the future is difficult to predict because of the inflation of dollars and the tremendous rise in expenses during the past years. However, twenty still thought that they could support themselves adequately while three felt that they probably would be in a precarious situation. All of these are married. Two of them have children and one has no children yet. Their spouses, being the wives of students, were not allowed to work. 
CHAPTER IV

CONCLUSION

The most important, and surprising finding of the survey was that the financial problem was not as critical as might be thought.

\section{$\underline{\text { Housing }}$}

Although housing was the major expense, students managed to live in reasonably comfortable accommodations. However, the facilities of student housing was considered to be less than ideal. One or two of the student houses were considered to be poorly managed. Students, especial1y foreign students, who had to be more careful in spending their money had to bear with resulting unfavourable living conditions. An International Student House was not available at Portland State University for foreign students for temporary stay when they first arrived. Students had to pay for high rent for the first few months before their housing problem could be properly settled.

\section{Food}

Students considered their health as the top priority. Therefore, sufficient diet was important. They would not consider cutting down food supply to meet their budget. A number of students were engaged in jobs in restaurants or cafeterias because this kind of job was easier to find and also because meals would be provided while working. It could help to reduce the expenses in food and also save time in cooking. Usually students were provided with one meal a day by the restaurant or cafeteria 
where they were working.

Work

In spite of the restriction of immigrant ordinance in terms of employment, students still have no problem in securing jobs with reasonable wages withjn a short period of time. Working, regardless of the kind of job, became an acceptable value among Chinese students. This might go along with the American cultural values of self-support and a spirit of independence shared by Chinese. Students were capable of supporting themselves sufficiently without slaving themselves in work. However, students in Portland State University were lacking in guidance from the authority concerned in connection with their work. It is also true that vocational counseling offered by the Counseling Center in Portland State University could only give counseling on an individual's potential in connection with his job but had no knowledge about the complications the foreign students encountered in the working situation. Students seldom approached the Foreign Student Advisor for assistance. They were not convinced, through experience or minconception, that they would receive any helpful information from this source. Students probably would not approach for advice if they were working without a work permit. The working situation became problematic: Most of the students felt that it would be more secure for them and at the same time they would have more job alternatives if they could have a work permit, even though they would go on working with or without the permit.

\section{Financial Situation}

Students were mostly financially stable. Besides, securing jobs was not too much of a problem. There are causes that led to this status. 
Restrictive immigration regulations had limited the number of Chinese students who wanted to come to the United States. As financial document is required to be produced before approval of visa. The document is to prove the financial competence to cover the expenses for the whole study program. As this regulation has become more rigid during recent years, the majority of students who can come to study abroad will belong to families of a higher economic status. On the other hand, the university is more relaxed in offering jobs to foreign students for work on campus even though some of the study projects are those for which foreign students are not eligible to apply; for example, Work Study Projects. Furthermore, foreign students, especially Chinese students, are willing to accept almost any job offers. Minimum wage laws protect against exploitively inadequate hourly wages.

\section{Financial Assistance}

Financial assistance from Foreign Student Aid can help quite a number of students though the service is still not extended to all students in need. Financial resources which students can approach are scarce either in the University or in the community. Foreign students are not eligible for food stamps or welfare. There is also no financial aid from any of the Chinese Associations. If an emergency happened some students would be in a crisis situation. If the Chinese Student Association of Portland State were systematically organized and supported by all the Chinese students, it might be possible to establish an emergency fund donated by students, to help those in an emergency.

Implications for Social Work

Students who come from other countries need as much help as possible 
from the host country especially at the beginning of their arrival. The Foreign Student Advisor is the best place and is the first place where students could approach for help. As described by Blegen and his assoclates and quoted by Cieslak:

The primary task of the foreign student advisor is professional counseling. It involves interviewing and counseling forelgn students who seek assistance in the solution of their personal, family, vocational and educational problems, as well as problems relating to currency exchange, visas, passports, government regulations, and other legal and technical matters. It includes also specialized services to all students from other countries in matters of admission, college requirements, housing, finances, orientation to American culture, social regulations, and language problems. It means systematic and periodic interview to obtain information about the foreign student's background and individual need for guidance in a new and unfamiliar culture. It means analysis and appraisal of the status, liabilities, and assets of each foreign student. It means giving assistance in planning his educational and recreational program so that he may adjust as effectively as possible to new environment. 1

However, this survey revealed that Chinese foreign students seldom made use of this service. It might be due partly to the culture of Chinese students who were reserved in asking for cutside help, especially those with language difficulty. It also might be due to their experience with this service when they first contacted it. If students did not get the kind of services they needed once, they might not use this service again.

A social worker placed in this office might facilitate their service in many ways. The social worker can share the responsibility of the advisor in counseling foreign students, especially at the beginming of the term when many new students were enrolled and in need of help or orientation desperately, regarding such things as housing,

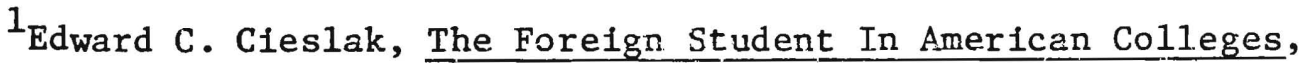
(Detroit: Wayne University Press, 1955), P. 98. 
purchasing secondhand books, utensils, using 1ibrary, and social activaties. It would be an ideal to have a Chinese social worker available because Chinese students would find it easier to talk about their problems with a person of the same cultural background. Besides, language barriers can be eliminated. However, even if this could not work out, a social worker or even a student social worker would be very helpful, not only would the counseling techniques which the worker could use help to relieve students' anxiety in the unfamiliar environment, but the knowledge of community resources would also help foreign students to adopt to this society more easily or solve their problem more effectively. A social worker also could help to give job counseling. Students who were facing financial problems are in need of assistance to solve the problem as well as psychological support. Counseling services would help to relieve the emotional burden of the students who then might be able to assess their situation calmly and intelligently; thus proper resolution would be found. On the other hand, a social worker can help to gather information in order to assess the student's situation on which the decision of recommendation for a work permit can be based. It would be more helpful than asking the student to "write a statement about the change of situation if you wanted to apply for a work permit." Students were usually discouraged by this attitude. The other important value of appropriate counseling service in time is in helping the student to make use of this experience in a positive way so that he might be able to deal with future crises more adequately. More activites should be organized by International Student. Services and the Chinese Student Association in order to connect the foreign students with social life. Foreign students are in need of 
social life to help them to get away from their depressive feeling such as homesickness and loneliness. It is important to initiate them to Join the group. Correspondence is more useful than posters only for activities announcement. Regular printed matter published by the Chinese Student Association could help the students keep up to date with the developments of the organization. The more the students know about the Association the more apt they would be to participate.

An emergency fund might also be a good way for the Association to get involved with the welfare of students. Further exploration along this line among Chinese students is worth trying. With more information a more organized plan can be set up. Donations from the students would not be a difficult task if students recognized the Assocation as one of the helping resources. If more organized ways can be available to help Chinese students by the Chinese Student Association to the newcomers they can then adjust to their financial and other problems more appropriately and effectively. This is an important function for the Chinese Student Assocation to carry because Chinese foreign students would attempt to approach this source for assistance when they arrived. Disappointment by the poor service would intimidate and discourage them in asking for outside help later.

Discussion

Any questions which are connected with the financial situation are touchy for Chinese as it is not a common practice for Chinese to reveal their personal lives to other people. Much reassurance and support had to be given before the questions would be answered, particularly those referring to employment and work permit. The form of interview was 
helpful because during the process I could relieve the interviewees' suspicions and at the same time avoid unresponded questions. It also decreased the probability of false information. Nevertheless, there is independent evidence that in two or three instances dissimilation occurred with reference to working status. Future studies may throw light on the adequacy of this study and its reliability. While nearly all students find themselves adequately able to meet a11 but unforeseen events, this study only indicates the adjustments and anxieties underlying the achievement of this status. It is rare for the abie student from a poor or even average family to be admitted to this country. Whether this is a deliberate social policy or not, it has important consequences both individually and socially. Meanwhile, we continue without the resources needed to protect those students who do find themselves in precarious circumstances. 


\section{BIBLIOGRAPHY}

Arkin, Herbert and Colton, Raymond R., Statistical Methods, Barnes \& Noble, Inc. New York, 1970

Becker, T., "Cultural Patterns \& Nationalistic Commitment Among Foreign Students in the U.S." Sociology \& Social Research, Vol. 55, July 1971

Cleslak, Edward Charnwood, The Foreign Student in American Colleges, Wayne University Press, Detroit, 1955

Clarke, Helen I. \& Ozawa, Martha, The Foreign Student In The United States, The University of Wisconsin, 1970

Dornbusch, Sanford M., \$ Schmid, Calvin F., A Primer of Social Statistics, McGraw-Hill Book Company, N.Y. 1955

Du Bois, Cora, Foreign Student And Higher Education In The United States, American Council on Education, Washington, D.C., 1956

Editor, "The Freshman's Problem" Economist, Vo1. 227 No. 6503, April 13, 1968

Editor, "Learn Now, Pay Later" Economist, Vo1. 229 No. 6531, October 26, 1968

The Foreign Student: Whom Shall We Welcome? Education and World Affairs, New York, 1964

Elde, Ingrid (Ed.), Students As Links Between Cultures, Unesco, and the International Peace Research Institute, 0s1o, 1970

Fong, Linda, Occupational Prestige Among Chinese In The San Francisco Area, Portland State University, Oregon, 1974

Hu, Terry Shu-Fang, Adjustment Problems of Chinese College Students In The United States, Portland State University, Oregon, 1974

Lindgren, Henry Clay, The Psychology of College Success, John Wiley \& Sons, Inc. New York, 1969

Mechanic, David, Students Under Stress, The Free Press of Glencoe, 1962

Morris, Richart T., The Two-Way Mirror, The University of Minnesota Press, Minneapolis, 1960

Parad, Howard J. (Ed.), Crisis Intervention: Selected Readings, Family

- Service Association of America, New York, 1965

United Nations Educational, Science and Cultural Organization -- Document. Paris, UNESCO, 1972

Williamson, E.G. \& Darley, J.G., Student Personnel Work, McGraw-Hill Book Company, London, 1937 
Young, Kimball, Personality \& Problems of Adjustment, Appleton-CenturyCrofts, Inc. N.Y. 1952

Yuan, D.Y., "Division of Labour Between Native Born and Foreign-Born Chinese in the United States: A Study of Their Traditional Employment." Phylon Sunmer, 1969 


\section{APPENDIX I}

\section{SCHEDULE}

ECONOMIC COPING PATTERNS OF CHINESE FOREIGN STUDENTS

IN PORILAND STATE UNIVERSITY

1. Sex

2. Educational level:
1) Undergraduate
2) Graduate

3. Place where you come from:
1) Hong Kong
2) Taiwan

4. Your major field of study in PSU

5. You are living:
1) alone
2) with spouse alone
3) with children and spouse
4) with children alone
5) with relatives
6) with friends
7) other

6. Year of arrival

7. What kind of accommodation:
1) student housing
2) house
3) apartment
4) room
5) other

8. What monthly proportion of expenses has gone for:
1) housing
2) food
3) clothing
4) transportation
5) miscellaneous

9. How often have you been without sufficient money to meet your needs?
1) almost never
2) seldom
3) sometimes
4) often
5) nearly always 
10. What is your source of income now?

1) family

2) employment

3) savings

4) financial aid

5) loans

6) other

11. If from family:

1) who gives you money?

(a) parents

(b) siblings

(c) spouse

(d) other relatives

2) How much on average per quarter?

3) How would you describe your family financial postion?

(a) upper class

(b) upper-middle class

(c) middle class

(d) lower-middle class

(e) lower class

12. If from employment:

1) How long did it take you to get your first job?

2) When do you work?

(a) during school terms

(b) in summer

(c) between quarter breaks

3) What kind of place are you working?

4) What kind of job?

(a) now

(b) during summer

(c) during quarter breaks

5) How many working hours per week?

(a) now

(b) during summer

(c) during quarter breaks

6) What are or were your wages per hour?

(a) now

(b) during summer

(c) during quarter breaks

7) Are you working?

(a) on campus

(b) off campus 
8) When did you first realize that a work permit is required while working off campus?

(a) before coming to U.S.A.

(b) upon arrival

(c) after arriva1

(d) just now

9) Have you tried to apply for a work permit?

(a) yes

(b) no

13. If from savings:

1) How much money did you have before you came?

2) How long did you plan to use this sum of money?

3) Compared with your expectation, how long has that money lasted?

14. If from financial aid:

1) What is the name of the aid?

2) How much per quarter?

3) When did you apply for it?

(a) before you came

(b) upon arrival

(c) after arrival

4) How long did it take after application before they granted you the money?

5) About what proportion of your expenses are covered by aid (neaxest fraction)?

(a) all

(b) about $3 / 4$

(c) about $1 / 2$

(d) about $1 / 4$

15. If from loans:

1) from where?

2) How much in tota1?

3) How much for annual interest (if any)?

4) When will you be expected to repay it?

5) You will repay it by:

(a) monthly installments (How long?)

(b) lump sum

(c) your services in the organization

(d) other 
16. In order to keep within your budget what would you probably do?

1) cut down food supply

2) live in places with cheaper rent

3) find employment

4) change employment for higher pay

5) other

17. In the event of financial crisis, whom will you approach for help? (name three of them with numbers according to your own priority)
1) family
2) relatives
3) friends
4) associations
5) Consulate from home country
6) foreign student advisor
7) financial aid office
8) Chinese Student Association of PSU
9) other

18. What were your reasons for studying abroad?

1) parents' idea only

2) cannot further your study in your home country

3) for new experience

4) peer group value in home country

5) can find a job easier with U.S.A degree in home country

6) have a chance to become an immigrant here

7) other

19. Do you find you are accomplishing what you expected by studying abroad?

1) a great deal

2) some

3) 1ittle

4) very little

5) not sure

20. Name the three most important positive things which you would not have had a chance to experience in your home country.

21. Name the three most difficult situations which frustrated you most.

22. Can you use one sentence to describe your feeling about your financial situation? 